\title{
The Paleobiolinguistics of Domesticated Manioc (Manihot esculenta)
}

\author{
Cecil H. Brown ${ }^{1 *}$, Charles R. Clement ${ }^{2}$, Patience Epps ${ }^{3}$, Eike Luedeling ${ }^{4}$, and Søren Wichmann ${ }^{5}$
}

Author address: ${ }^{1}$ Northern Illinois University, 1700 Scenic Highway, \#601, Pensacola, FL, 32503-6634, USA, ${ }^{2}$ Instituto Nacional de Pesquisas da Amazônia, Manaus, AM, Brazil, ${ }^{3}$ University of Texas at Austin, Austin, TX, USA, ${ }^{4}$ World Agroforestry Centre (ICRAF), Nairobi, Kenya, ${ }^{5}$ Max Planck Institute for Evolutionary Anthropology, Leipzig, Germany. ${ }^{*}$ Corresponding author: brown.cecil@yahoo.com

Received: January 21, 2013

Volume: 4:61-70

Published: June 26, 2013

(C) 2013 Society of Ethnobiology

\begin{abstract}
Paleobiolinguistics is used to identify on maps where and when manioc (Manihot esculenta) developed importance for different prehistoric groups of Native Americans. This information indicates, among other things, that significant interest in manioc developed at least a millennium before a village-farming way of life became widespread in the New World.
\end{abstract}

Key Words: Archaeobotany, crop origins, historical linguistics, Native American Indians, paleobiolinguistics, plant domestication, plant genetics

Paleobiolinguistics (PBL) employs the comparative method of historical linguistics to reconstruct the biodiversity known to human groups of the remote, unrecorded past (Brown et al. 2013a; Brown et al. 2013b). ${ }^{1}$ Comparison of words for biological taxa from languages of the same language family facilitates reconstruction of the biological vocabulary of the family's ancient proto-language. This study uses PBL to establish where and when domesticated manioc (Manihot esculenta Crantz, Euphorbiaceae) developed significance for different prehistoric Native American groups. This entails mapping in both time and geographic space proto-languages for which words for manioc reconstruct.

The approximately 98 species of Manihot are all native to the New World. There are two centers of diversity of Manihot. One is in Mesoamerica, which current evidence indicates may be the place of origin of the genus, with approximately 17 species; and the other is in Brazil, with approximately 80 species (Duputié et al. 2011). The only domesticated taxon is M. esculenta ssp. esculenta, which is derived from ssp. flabellifolia. This subspecies is widely distributed in tropical South America in seasonal open forests both north and south of the Amazon basin, and extending into the Brazilian savannas (Allem 2002). Work during the last decade establishes that ssp. esculenta was brought into domestication somewhere in what are today northwestern Mato Grosso, Rondônia, and eastern Acre, Brazil, and in immediately adjacent areas in lowland Bolivia (Schaal et al. 2006). Populations of ssp. flabellifolia in northern South America are shown by Léotard et al. (2009) not to be involved in domestication, and other species in Mesoamerica and South America are ruled out by Duputié et al. (2011).

Manioc can be lethally toxic if not prepared correctly. The presence of cyanogenic glucosides in the roots varies from less than 10 to more than 500 mg hydrogen cyanide (HCN) per kilo on a fresh weight basis; varieties with less than $100 \mathrm{mg} / \mathrm{kg}$ are considered sweet, and those with more are considered bitter (McKey et al. 2010) and require processing for consumption. While sweet and bitter varieties are difficult to distinguish morphologically, farmers typically are able to segregate bitter from sweet in their production systems (McKey and Beckerman 1993). Initial human selection probably favored the development of sweet varieties, which are more widely distributed in South America and through Central America to Mexico than bitter varieties (Arroyo-Kalin 2010). When food production systems started supplying significant proportions of human diets between 4000 and 3000 BP (Piperno and Pearsall 1998), bitter varieties were selected for toxicity to protect against pests and to provide higher yields (Arroyo-Kalin 2010). Bitter varieties are most common in Central and Eastern Amazonia and the Guianas, with sweet varieties being more prevalent in 
Table 1. Manioc-term reconstruction for proto-languages of Mesoamerica (Southern Mexico and Northern Central America).

\begin{tabular}{|c|c|c|c|c|c|}
\hline $\begin{array}{l}\text { Years } \\
\text { Before } \\
\text { Present }\end{array}$ & Proto-Language & $\begin{array}{l}\text { Proto-Word for } \\
\text { Manioc (NR = Not } \\
\text { Reconstructable) }\end{array}$ & $\begin{array}{l}\text { Homeland Center } \\
\text { Geographic } \\
\text { Coordinates }\end{array}$ & Family Affiliation & $\begin{array}{l}\text { Proto-Word } \\
\text { Source }\end{array}$ \\
\hline 6591 & Otomanguean & *ya & $18,-96.92$ & Otomanguean & 1 \\
\hline 5498 & $\begin{array}{l}\text { Popolocan- } \\
\text { Zapotecan }\end{array}$ & *ya & $17.17,-96.17$ & Otomanguean & Authors \\
\hline 4274 & Totozoquean & *pisi: & $19.92,-97.42$ & Totozoquean & 2 \\
\hline 3149 & Zapotecan & *ko: yaka & $17.17,-96.17$ & Otomanguean & Authors \\
\hline 3036 & Popolocan & *ya & $18,-96.92$ & Otomanguean & Authors \\
\hline 2445 & Chiapanec-Mangue & *yá? & $17.07,-92.73$ & Otomanguean & 3 \\
\hline 2220 & Mayan & *tz'ihn & $15.42,-91.83$ & Mayan & 4 \\
\hline 1935 & Chinantecan & $* ? m a^{L}$ & $17.92,-96.5$ & Otomanguean & 5 \\
\hline 1676 & Zapotec & ko yaka & $17.17,-96.17$ & Otomanguean & Authors \\
\hline 1649 & Quichean-Mamean & $*$ tz'iin & $15.42,-91.83$ & Mayan & 4 \\
\hline 1596 & Mixe-Zoquean & $*$ pisi & $17.22,-96.03$ & Totozoquean & 6 \\
\hline 1520 & General Aztec & ${ }^{*} \mathrm{k}^{\mathrm{w}}$ aw-kamo? & $18.35,-99.83$ & Uto-Aztecan & Authors \\
\hline 1492 & Greater Mamean & $*_{\text {tz'iin }}$ & $15.42,-91.83$ & Mayan & 4 \\
\hline 1435 & Totonacan & *qoqšqęwi & $19.92,-97.42$ & Totozoquean & 7 \\
\hline 1432 & Cholan-Tzeltalan & $*_{\text {tz'ihn }}$ & $16.83,-92.83$ & Mayan & 4 \\
\hline 1225 & Kanjobalan-Chujean & $*_{\text {tz'iin }}^{\prime}$ & $15.83,-91.83$ & Mayan & 4 \\
\hline 1148 & Cholan & $*_{\text {tz'ihn }}$ & $14.81,-89.38$ & Mayan & 4 \\
\hline 1058 & Chujean & $* t z^{\prime}$ in & $15.92,-91.58$ & Mayan & 4 \\
\hline 997 & Chatino & *ko: yaka & $16.25,-97.38$ & Otomanguean & Authors \\
\hline 981 & Greater Quichean & $*^{t} z^{\prime}$ iin & $14.78,-91.5$ & Mayan & 4 \\
\hline 900 & Mixe & *kuhy-piši & $17.02,-96.07$ & Totozoquean & 6 \\
\hline 802 & Kanjobalan & *tz'iin & $15.83,-91.83$ & Mayan & 4 \\
\hline 790 & Yucatecan & $*^{t} z^{\prime}$ iin & $20,-89$ & Mayan & 4 \\
\hline 787 & Zoque & $*$ pisi & $16.9,-94.68$ & Totozoquean & 6 \\
\hline 511 & Tzeltalan & $*_{\mathrm{tz}}^{\prime}$ in & $16.83,-92.83$ & Mayan & 4 \\
\hline
\end{tabular}

$\begin{array}{ll}\text { Proto-Word Source: } & \text { 4. Brown and Wichmann } 2004 \\ \text { 1. Kaufman 1990 } & \text { 5. Rensch 1989 } \\ \text { 2. Brown et al. 2011 } & \text { 6. Wichmann 1995 } \\ \text { 3. Rensch 1976 } & \text { 7. David Beck, pers. com. }\end{array}$

the basin's headwaters (McKey and Beckerman 1993). Bitter varieties were also once common along coastal Brazil, but now are rare.

Isendahl (2011) reviews the archaeobotanical evidence for cultivated manioc, with oldest dates of approximately $8000 \mathrm{BP}$ for remains from the Pacific coast of Peru and low-elevations of the Colombian Andes, 5000 BP for lowland Amazonian Colombia,
7000 BP for Panama, and 6500 BP for Mexico. Arroyo-Kalin (2010) cautions that early dates for manioc may not always be M. esculenta, since the genus is widely distributed and other species may have been brought into domestication and later abandoned with the arrival of modern manioc. However, given that other Manihot species are absent from coastal Peru and the Colombian Andes (Duputié et al. 2011), the 


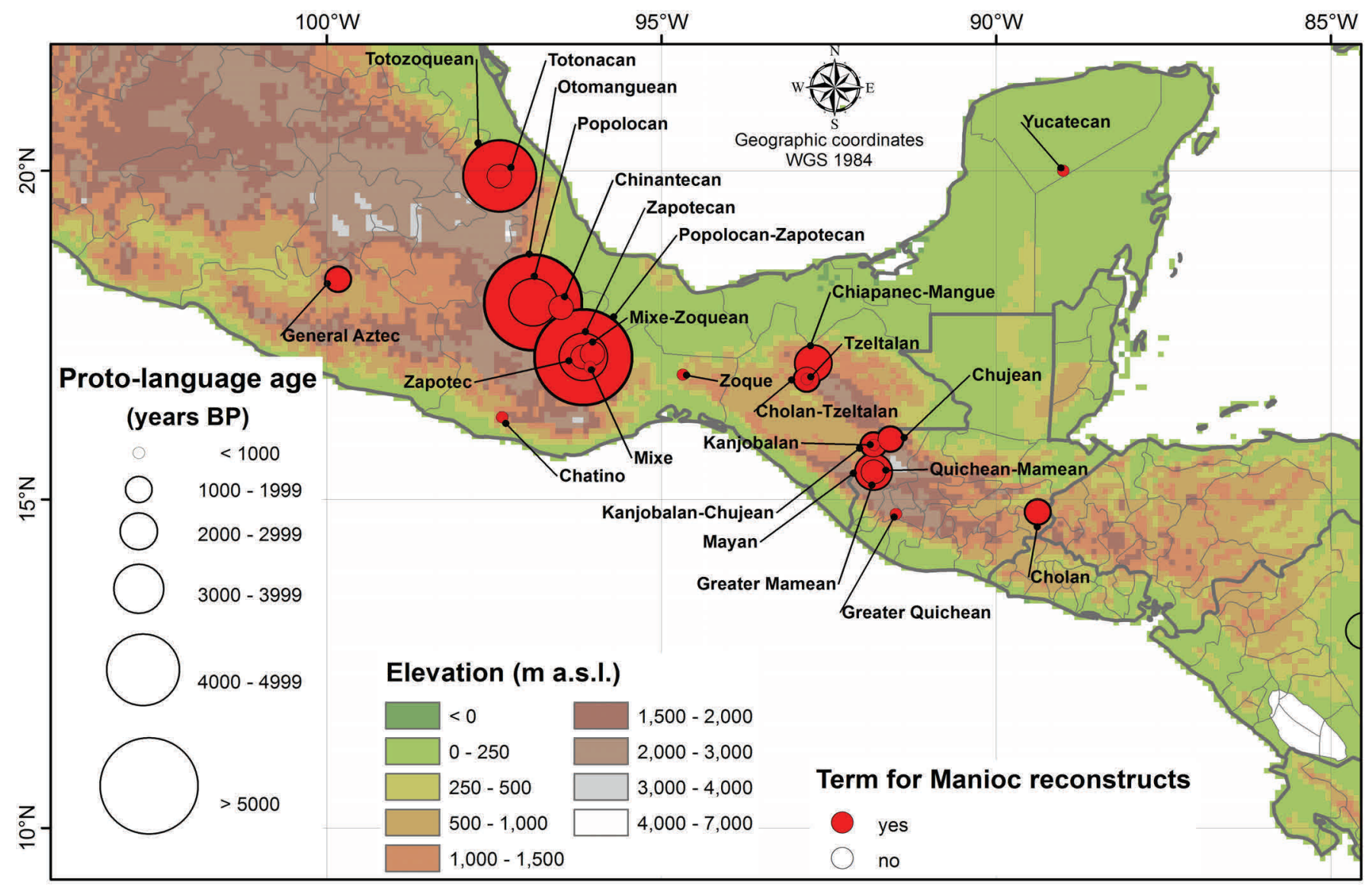

Figure 1. Manioc-term reconstruction information from Table 1 plotted on map of Mesoamerica.

earliest dates in these regions are likely to represent the introduction of M. esculenta from its center of domestication in southwestern Amazonia.

Manioc-term reconstructions are presented for proto-languages of two major regions of the New World: (1) Southern Mexico and Northern Central America (henceforth Mesoamerica) (Table 1); (2) Southern Central America and South America (Table 2). North America is not included in this analysis because manioc was a historical introduction there.

The tables list major proto-languages of the Americas widely regarded by historical linguists as demonstrated. Some major proto-languages are not included because lexical information from daughter languages is not sufficiently available for drawing either positive or negative conclusions about maniocterm reconstruction. Unfortunately, words for sweet and bitter varieties are insufficiently recorded in sources to permit a reconstructed distinction. In addition to identifying proto-languages with manioc terms and the terms themselves, the tables report proto-languages for which these terms are "not reconstructable" (NR). NR is a designation used when terms for manioc are present in all or most languages of a family, but, nonetheless, are not cognate and, hence, do not attest to a manioc term in their shared ancestral language. NR, then, never indicates that a term does not reconstruct because of missing data.

Dates for proto-languages presented in the tables are intended to be the latest dates at which these languages were spoken just before breaking up into daughter languages. These are calculated through use of Automated Similarity Judgment Program (ASJP) chronology, a computational dating approach based on the lexical similarity of languages (Holman et al. 2011). ${ }^{2}$ Possible geographic coordinates for protolanguage homeland centers given in the tables are produced through automation using an algorithm for identifying the maximum lexical diversity within a language family (Wichmann et al. 2010). The geographic center of lexical diversity of a family is assumed to correlate with where the family's protolanguage was spoken. Tables also give a linguistic 
Table 2. Manioc-term reconstruction for proto-languages of Southern Central America and South America.

\begin{tabular}{|c|c|c|c|c|c|}
\hline $\begin{array}{l}\text { Years } \\
\text { Before } \\
\text { Present }\end{array}$ & Proto-Language & $\begin{array}{l}\text { Proto-Word for } \\
\text { Manioc (NR = Not } \\
\text { Reconstructable) }\end{array}$ & $\begin{array}{l}\text { Homeland Center } \\
\text { Geographic } \\
\text { Coordinates }\end{array}$ & Family Affiliation & Proto-Word Source \\
\hline 7266 & Macro-Ge & NR & $-11.3,-53$ & Macro-Ge & \\
\hline 4701 & Mataco-Guaykuru & NR & $-22.5,-62.58$ & $\begin{array}{l}\text { Mataco- } \\
\text { Guaykuru }\end{array}$ & \\
\hline 4461 & Southern Arawakan & *kaniri & $-10.33,-74.33$ & Arawakan & Authors \\
\hline 4400 & Chibchan & *Pik, *ike & $9.75,-83.42$ & Chibchan & 1,2 \\
\hline 4134 & Arawakan & $*_{k a n i}\left[t^{\mathrm{h}} \dot{\mathrm{t}}\right]$ & $1,-69.17$ & Arawakan & 3 \\
\hline 4085 & N Arawakan & *kani[ti] & $1,-69.17$ & Arawakan & Authors \\
\hline 3943 & Panoan-Tacanan & NR & $-7.5,-75$ & Panoan-Tacanan & \\
\hline 3585 & Tupi & *mani & $-8,-62$ & Tupi & 4 \\
\hline 3518 & Caribbean N Arawakan & *kani & $12,-72$ & Arawakan & Authors \\
\hline 3310 & Salivan & NR & $5,-67$ & Salivan & \\
\hline 3241 & Barbacoan & *ku- & $0.67,-79$ & Barbacoan & Authors \\
\hline 3178 & Zaparoan & *muriha & $-3.25,-74$ & Zaparoan & 5 \\
\hline 3124 & Nadahup & NR & $0,-69$ & Nadahup & \\
\hline 3023 & $\mathrm{Ge}$ & *kwyr & $-15,-52.5$ & Macro-Ge & 6 \\
\hline 2927 & Witoto-Ocaina & *hõ?ti & $-2.75,-71.75$ & $\begin{array}{l}\text { Witoto-Ocaina- } \\
\text { Nonuya }\end{array}$ & 7 \\
\hline 2909 & Guaykuruan & NR & $-26.5,-59$ & $\begin{array}{l}\text { Mataco- } \\
\text { Guaykuru }\end{array}$ & \\
\hline 2857 & Witoto-Ocaina-Nonuya & *hoptit & $-1.25,-72.5$ & $\begin{array}{l}\text { Witoto-Ocaina- } \\
\text { Nonuya }\end{array}$ & 8 \\
\hline 2807 & Nambiquaran & $*\left(w v^{3}\right) \operatorname{lin}^{\prime 3}$ & $-12.75,-59.17$ & Nambiquaran & 9 \\
\hline 2774 & Misumalpan & NR & $13,-84.5$ & Misumalpan & \\
\hline 2731 & Talamancan & $*_{\mathrm{ik}}$ & $9.75,-83.42$ & Chibchan & Authors \\
\hline 2699 & Tucanoan & $*_{\mathrm{kij}}$ & $0.33,-70.25$ & Tucanoan & 10 \\
\hline 2593 & Inland N Arawakan & $\begin{array}{l}\text { *kainhi, *kap(w)a- } \\
\text { li, *mulhui }\end{array}$ & $1,-69.17$ & Arawakan & 11 \\
\hline 2503 & Venezuelan Cariban & *kičere, *amaka & $6.5,-66$ & Cariban & Authors \\
\hline 2433 & Southern Guaykuruan & *piyok & $-26.5,-59$ & $\begin{array}{l}\text { Mataco- } \\
\text { Guaykuru }\end{array}$ & Authors \\
\hline 2414 & North Barbacoan & *ku- & $1.5,-78.25$ & Barbacoan & Authors \\
\hline 2412 & Cariban & *kï(č/t)ere, *wïj(u) & $10.17,-72.75$ & Cariban & 12 \\
\hline 2404 & Matacoan & NR & $-22.5,-62.58$ & $\begin{array}{l}\text { Mataco- } \\
\text { Guaykuru }\end{array}$ & \\
\hline 2271 & Boran & $\begin{array}{l}\text { *piikkaá, } \\
\text { *paikoómi }\end{array}$ & $-2.17,-72.33$ & Boran & 7, Authors \\
\hline 2219 & Purus & *kanwrw & $-12.5,-69.33$ & Arawakan & Authors \\
\hline 2156 & Western Tucanoan & $* k+i$ & $-2.83,-72.5$ & Tucanoan & Authors \\
\hline 1931 & Chapacuran & *Pakop & $-13.43,-63.17$ & Chapacuran & 13 \\
\hline 1853 & Panoan & *?atsa & $-7.5,-75$ & Panoan-Tacanan & Authors \\
\hline 1853 & Pekodian & $*_{u}$ & $-14,-55$ & Cariban & Authors \\
\hline 1850 & Tupari & $*$ mani & $-12.5,-62.5$ & Tupi & Authors \\
\hline
\end{tabular}

(continued on next page) 
(continued from previous page)

\begin{tabular}{|c|c|c|c|c|c|}
\hline $\begin{array}{l}\text { Years } \\
\text { Before } \\
\text { Present }\end{array}$ & Proto-Language & $\begin{array}{l}\text { Proto-Word for } \\
\text { Manioc (NR = Not } \\
\text { Reconstructable) }\end{array}$ & $\begin{array}{l}\text { Homeland Center } \\
\text { Geographic } \\
\text { Coordinates }\end{array}$ & Family Affiliation & Proto-Word Source \\
\hline 1821 & Southern Ge & $*$ kubs\{d\}, *kagre & $-26,-52$ & Macro-Ge & 14 \\
\hline 1780 & Mascoian & *seppo & $-23.2,-58$ & Mascoian & Authors \\
\hline 1764 & Arauan & $\begin{array}{l}\text { *po'a, *ximeka, } \\
\text { *kojo }\end{array}$ & $-6,-70.5$ & Arauan & 15 \\
\hline 1717 & Quechuan & NR & $0.33,-78$ & Quechuan & 16 \\
\hline 1712 & Monde & NR & $-10.97,-61.13$ & Tupi & \\
\hline 1634 & Mainline Panoan & *?atsa & $-7.5,-75$ & Panoan-Tacanan & 17 \\
\hline 1607 & Jabuti & ${ }^{*}$ mure & $-12.25,-62.25$ & Macro-Ge & 18,19 \\
\hline 1590 & Tacanan & *kwawe & $-13.33,-66.5$ & Panoan-Tacanan & 20 \\
\hline 1569 & Harakmbet & *táare & $-12.5,-70.5$ & Harakmbet & 21 \\
\hline 1550 & Tupi-Guarani & ${ }^{*}$ mani & $-8,-62$ & Tupi & 5 \\
\hline 1519 & Kampan & *kaniri & $-10.33,-74.33$ & Arawakan & Authors \\
\hline 1480 & Munduruku & *masik & $-7,-58$ & Tupi & Authors \\
\hline 1418 & Cayapa-Colorado & *kuhcu & $0.67,-79$ & Barbacoan & 22 \\
\hline 1402 & Guianan Cariban & *kičere, *wii & $3.25,-55.75$ & Cariban & Authors \\
\hline 1395 & Cabecar-Bribri & *ali & $9.42,-83$ & Chibchan & Authors \\
\hline 1335 & Kakua-Nukak & $*_{\text {tũj }}$ & $0.88,-69.56$ & Kakua-Nukak & Authors \\
\hline 1319 & Yanomam & *naši & $3.5,-62.83$ & Yanomam & Authors \\
\hline 1291 & Guahiban & *newa, *bawá & $6.5,-71.33$ & Guahiban & 23, Authors \\
\hline 1262 & Timbira & *kwir & $-5.25,-46$ & Macro-Ge & 18 \\
\hline 1241 & Eastern Tucanoan & $* \mathrm{kii}$ & $0.33,-70.25$ & Tucanoan & Authors \\
\hline 1185 & Kawapanan & *ki? & $-5.5,-77$ & Kawapanan & 24 \\
\hline 1169 & Pemongan & *kisera & $4,-60$ & Cariban & Authors \\
\hline 992 & Taranoan & *wii & $1,-73$ & Cariban & 25 \\
\hline 974 & Quechua II & *rumu & $0.33,-78$ & Quechuan & 16 \\
\hline 678 & Jivaroan & *máma & $-2.5,-78$ & Jivaroan & 26 \\
\hline 644 & Guaymi & $*$ ho, *hi & $8.67,-82$ & Chibchan & Authors \\
\hline 419 & Coconucan & *lo & $2.5,-76.5$ & Barbacoan & Authors \\
\hline 414 & Witoto Proper & *huti, *maika(hi) & $-1,-73.5$ & $\begin{array}{l}\text { Witoto-Ocaina- } \\
\text { Nonuya }\end{array}$ & Authors \\
\hline 389 & Mayoruna Panoan & *Patsa & $-4.42,-70.25$ & Panoan-Tacanan & Authors \\
\hline
\end{tabular}

Proto-Word Source:

1. Constenla 1981

2. Constenla 1990

3. Payne 1991

4. Rodrigues 2010

5. Lev Michael, pers. com.

6. Davis 1966

7. Aschmann 1993

8. Echeverri and Seifart 2011
9. Price 1978

10. Chacon n.d.

11. Ramirez 2001

12. Sergio Meira, pers. com.

13. Angenot-de Lima 1997

14. Jolkesky 2010

15. Dixon 2004

16. Willem Adelaar, pers. com.

17. Shell 2008
18. Eduardo Ribeiro, pers. com

19. van der Voort 2007

20. Girard 1971

21. Matteson 1972

22. Moore 1962

23. Christian and Matteson 1972

24. Pilar Valenzuela, pers. com.

25. Meira 2000

26. Payne 1981 


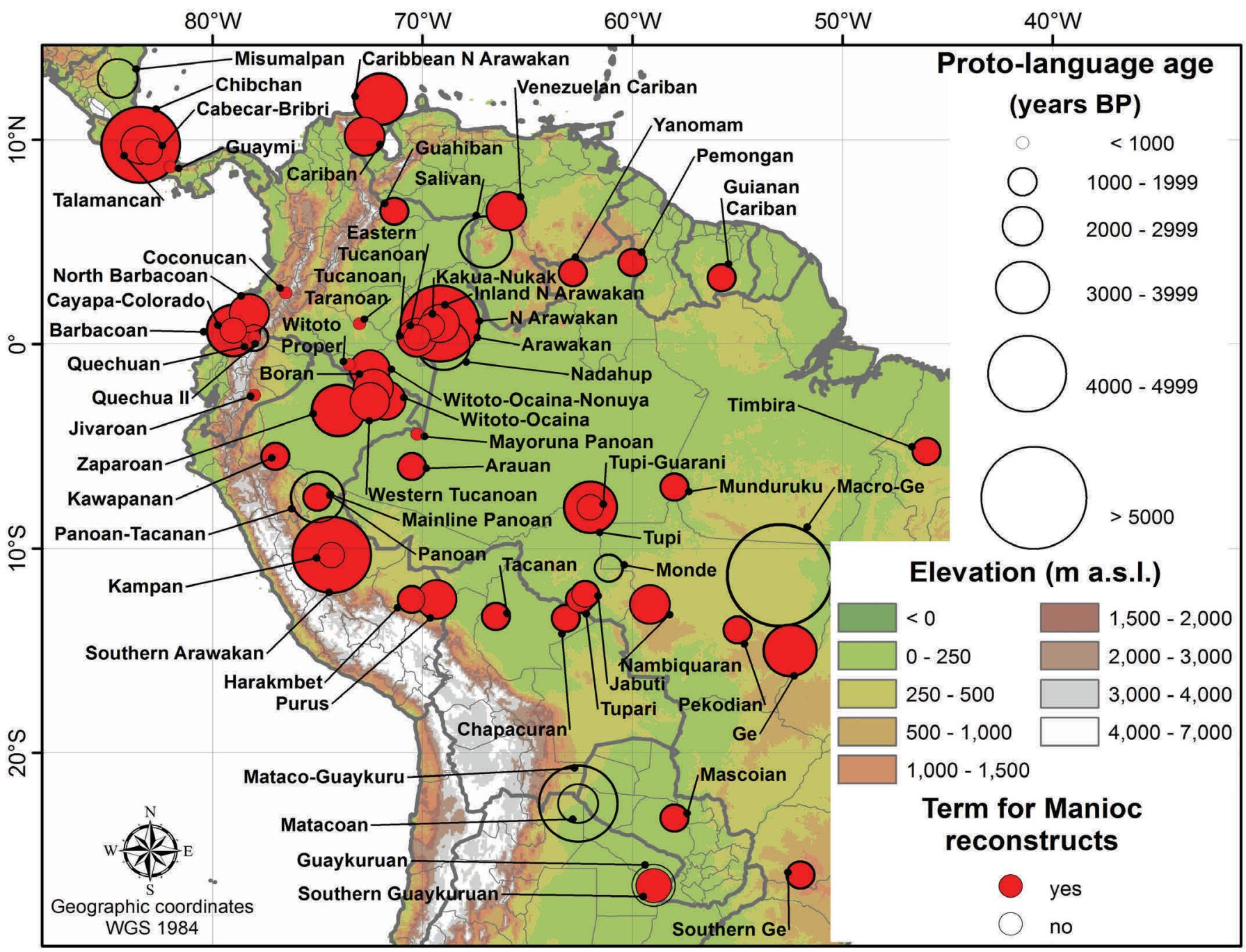

Figure 2. Manioc-term reconstruction information from Table 2 plotted on map of Southern Central America and South America.

family affiliation for each proto-language. The information reported in Tables 1 and 2 is plotted on maps of Figures 1, 2 and 3 to give a visual perspective on both the chronological and geographic distributions of reconstructed manioc terms. Figure 3 is an enlargement of a highly congested area of the map of Figure 2.

As noted above, manioc was originally domesticated somewhere in southwestern Amazonia (Schaal et al. 2006). This area includes the presumed Tupi homeland (Noelli 1998; Rodrigues 1964; Walker et al. 2012; and see Figure 2). Nevertheless, the ASJP date for Proto-Tupi is somewhat more recent (3585 BP, Table 2) than dates for other South American groups, especially Arawakan (4461-4085 BP, Table 2). The Arawakan homeland is near the 5000 BP-manioc remains reported from lowland Colombian Amazonia
(Isendahl 2011) and, thus, appears to reflect the dispersal of the crop from its center of domestication. From PBL analysis, there is no direct indication that speakers of any particular South American protolanguage were responsible for manioc domestication.

While archaeological evidence attests to the presence of manioc in Central America as early as 7000 BP (Isendahl 2011), the earliest date for a protolanguage in the area having a manioc term, i.e., Chibchan, is 4400 BP (Table 2). This 2600-year discrepancy may be more apparent than real considering, for example, that ASJP dates are minimum dates for proto-languages, i.e., latest dates at which ancestral languages were still spoken. The date for Otomanguean, 6591 BP (Table 1), of northern Mesoamerica, corresponds well with the archaeological date of $6500 \mathrm{BP}$ for the earliest remains of manioc in the area 


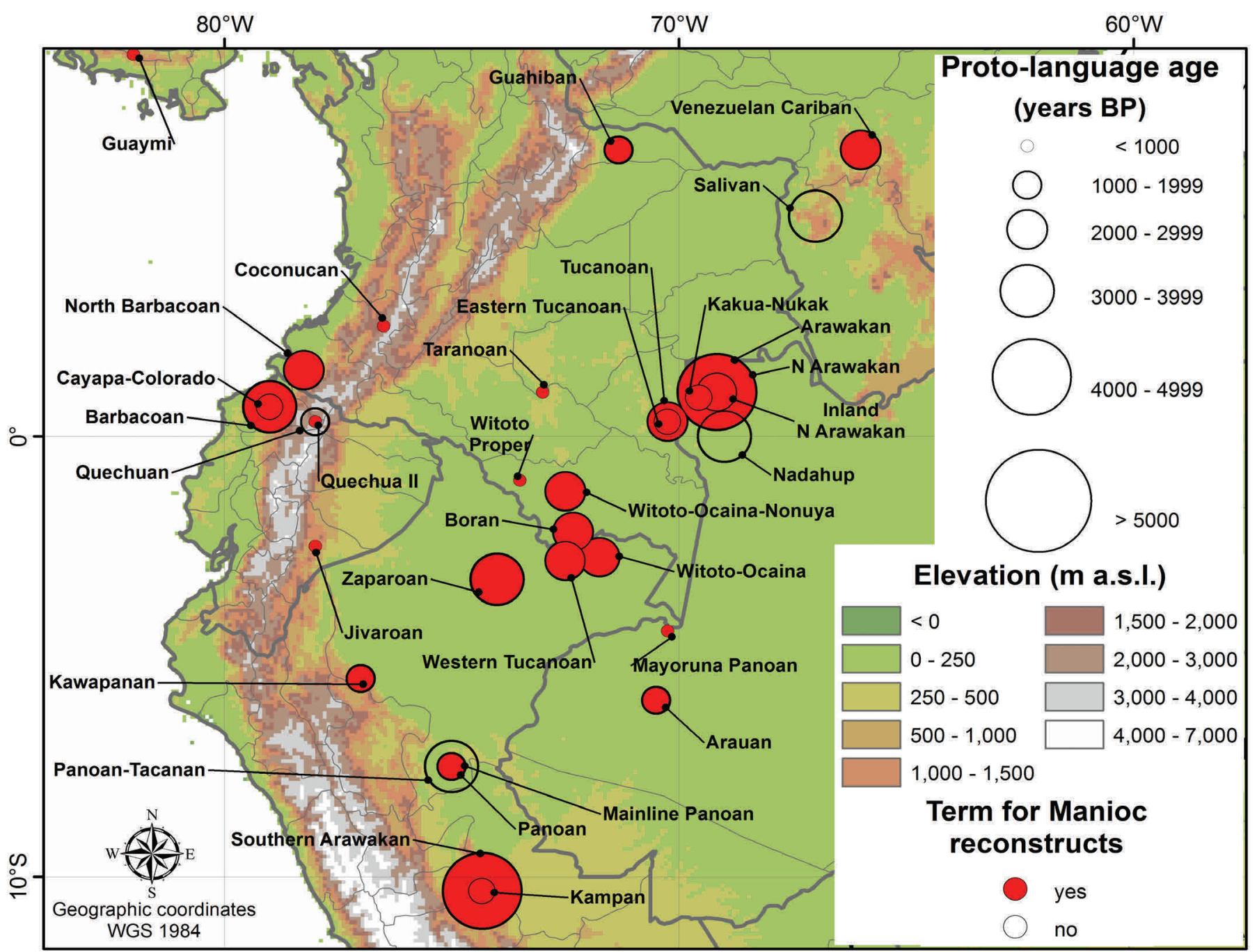

Figure 3. Enlargement of congested region (northwestern South America and adjacent areas) of map of Figure 2.

(Isendahl 2011). Notably, manioc reconstructs for all proto-languages of Mesoamerica (Figure 1), while this is not so for those of southern Central America and South America (Figure 2).

In general, proto-languages for which manioc terms reconstruct are broadly distributed through lowland South America and Mesoamerica, reflecting the crop's dispersal throughout the Neotropics from its origin in southwestern Amazonia. ASJP dates for these proto-languages, like archaeobotanical ones, indicate that domestication and dispersal of the crop occurred before the general development of a villagefarming way of life in the New World from 4000 to 3000 BP (Piperno and Pearsall 1998; Smith 1992).

\section{Acknowledgements}

We thank Jan Salick, Doyle McKey, Manuel ArroyoKalin, Christian Isendahl, two anonymous reviewers, and the editors for useful suggestions for improving this study. We are also grateful to Willem Adelaar, David Beck, Sergio Meira, Lev Michael, Eduardo Ribeiro, and Pilar Valenzuela for supplying linguistic data.

\section{Declarations}

Permissions: Not applicable.

Sources of funding: Epps' work on this project was supported by the National Science Foundation (HSD0902114).

Conflicts of interest: None declared. 


\section{References Cited}

Allem, A. C. 2002. The Origins and Taxonomy of Cassava. In Cassava, Biology, Production and Utilization, edited by R. J. Hillocks, J. M. Thresh, and A. C. Belloti, pp. 1-16. CAB International, Wallingford, UK.

Angenot de Lima, M. G. 1997. Fonotática e Fonologi do Lexema Protochapakura. Unpublished Master's Thesis, Universidade Federal de Rondônia.

Arroyo-Kalin, M. 2010. The Amazonian Formative: Crop Domestication and Anthropogenic Soils. Diversity 2:473-504.

Aschmann, R. P. 1993. Proto Witotoan. Summer Institute of Linguistics, Arlington, Texas.

Brown, C. H. 2006a. Glottochronology and the Chronology of Maize in the Americas. In Histories of Maize: Multidisciplinary Approaches to the Prehistory, Biogeography, Domestication, and Evolutions of Maize, edited by, J. E. Staller, R. H. Tykot, and B. F. Benz, pp. 648-663. Elsevier, San Diego.

Brown, C. H. 2006b. Prehistoric Chronology of the Common Bean in the New World: The Linguistic Evidence. American Anthropologist 108:507-516.

Brown, C. H. 2010. Development of Agriculture in Prehistoric Mesoamerica: The Linguistic Evidence. In Pre-Columbian Foodways: Interdisciplinary Approaches to Food, Culture and markets in Ancient Mesoamerica, edited by J. E. Staller and M. D. Carrasco, pp. 71107. Springer Science+Business Media, Berlin.

Brown, C. H., D. Beck, G. Kondrak, J. K. Watters, and S. Wichmann. 2011. Totozoquean. International Journal of American Linguistics 77:323-372.

Brown, C. H., C. R. Clement, P. Epps, E. Luedeling, and S. Wichmann. 2013a. The Paleobiolinguistics of Chili Pepper (Capsicum spp.). Ethnobiology Letters 4:111.

Brown, C. H., E. Luedeling, S. Wichmann, and P. Epps. 2013b. The Paleobiolinguistics of Domesticated Squash (Cucurbita spp.). In Explorations in Ethnobiology: The Legacy of Amadeo Rea, edited by M. Quinlan and M. D. Lepofsky, pp. 132-161. Society of Ethnobiology, Denton, Texas.

Brown, C. H., and S. Wichmann. 2004. Proto-Mayan Syllable Nuclei. International Journal of American Linguistics 70:128-186.

Chacon, T. n.d. A Revised Proposal of Proto-
Tukanoan Consonants and Tukanoan Family Classification. Forthcoming in International Journal of American Linguistics.

Christian, D. R., and E. Matteson. 1972. Proto Guahiban. In Comparative Studies in Amerindian Languages, edited by E. Matteson et al., pp. 150-159. Mouton, The Hague.

Constenla-Umaña, A. 1981. Comparative Chibchan Phonology.Unpublished Doctoral Dissertation, University of Pennsylvania.

Constenla-Umaña, A. 1990. Una Hipótesis sobre la Localización del Protochibcha y la Dispersión de sus Descendientes. Revista de Filología y Lingüística de la Universidad de Costa Rica 16:111-123.

Davis, I. 1966. Comparative Jê Phonology. Estudos Lingüisticos 1:10-24.

Dixon, R. M. W. 2004. Proto-Arawá Phonology. Anthropological Linguistics 46:1-83.

Echeverri, J. A. and F. Seifart. 2011. Una Reevaluación de las Familias Lingüísticas Bora y Witoto. Paper Presented at Congreso Arqueología y Lingüística Histórica de las Lenguas Indígenas Sudamericanas, Universidad de Brasília.

Duputié, A., J. Salick, and D. McKey. 2011. Evolutionary Biogeography of Manihot (Euphorbiaceae), a Rapidly Radiating Neotropical Genus Restricted to Dry Environments. Journal of Biogeography 38:10331043.

Girard, V. 1971. Proto-Takanan Phonology. University of California Press, Berkeley.

Holman, E. W., C. H. Brown, S. Wichmann et al. 2011. Automated Dating of the World's Language Families based on Lexical Similarity. Current Anthropology 52:841-875.

Isendahl, C. 2011. The Domestication and Early Spread of Manioc (Manibot esculenta Crantz): a Brief Synthesis. Latin American Antiquity 22:452-468.

Jolkesky, M. P. V. 2010. Reconstrução Fonológica e Lexical do Proto-Jê Meridional. Unpublished Master's Thesis, Universidade Estadual de Campinas.

Kaufman, T. S. 1990. Early Otomanguean Homeland and Cultures: Some Premature Hypotheses. University of Pittsburgh Working Papers in Linguistics 1:91-136. 
Léotard, G., A. Duputié, F. Kjellberg, E. J. P. Douzery, C. Debain, J. J. de Granville, and D. McKey. 2009. Phylogeography and the Origin of Cassava: New Insights from the Northern Rim of the Amazon Basin. Molecular Phylogenetics and Evolution 53:329-334.

Meira, S. 2000. A Reconstruction of Proto-Taranoan: Phonology and Morphology. Lincom Europa, München.

McKey, D., and S. Beckerman. 1993. Chemical Ecology, Plant Evolution and Traditional Manioc Cultivation Systems. In Tropical Forests, People and Food: Biocultural Interactions and Applications to Development, edited by C. M. Hladik, A. Hladick, O. F. Linares, H. Pagezy, A. Semple, and M. Hadley, pp. 83-112. Parthenon, Carnforth, UK, and UNESCO, Paris, France.

McKey, D., T. R. Cavagnaro, J. Cliff, and R. Gleadow. 2010. Chemical Ecology in Coupled Human and Natural Systems: People, Manioc, Multitrophic Interactions and Global Change. Chemoecology 20:109 $-133$.

Moore, B. R. 1962. Correspondences in South Barbacoan Chibcha. In Studies in Ecuadorian Indian Languages: I, edited by C. Peeke, pp. 270-289. Summer Institute of Linguistics, Norman, Oklahoma.

Noelli, F. 1998. The Tupi: Explaining origin and Expansions in Terms of Archaeology and of Historical Linguistics. Antiquity 72:648-663.

Payne, D. L. 1981. Bosquejo Fonológico del Protoshuar-candoshi: Evidencia para una Relación Genética. Revista del Museo Nacional 16:323-77.

Payne, D. L. 1991. A Classification of Maipuran (Arawakan) Languages Based on Shared Lexical Retentions. Handbook of Amazonian Languages 3:355499.

Piperno, D. R., and D. M. Pearsall. 1998. The Origins of Agriculture in the Lowland Neotropics. Academic Press, San Diego.

Price, P. D. 1978. The Nambiquara Linguistic Family. Anthropological Linguistics 20:14-37.

Ramirez, H. 2001. Linguas Arawak da Amazonia Setentrional. Editora da Universidade do Amazonas, Manaus.

Rensch, C. R. 1976. Comparative Otomanguean Phonology. Indiana University Publications, Bloomington.
Rensch, C. R. 1989. An Etymological Dictionary of the Chinantec Languages. Summer Institute of Linguistics, Arlington, Texas.

Rodrigues, A. 1964. A Classificação do Tronco Lingüístico Tupi. Revista de Antropologia 12:99-104.

Rodrigues, A. 2010. Linguistic Reconstruction of Elements of Prehistoric Tupi Culture. In Linguistics and Archaeology in the Americas: The Historization of Language and Society, edited by Eithne B. Carlin and Simon van de Kerke, pp. 1-10. London: Brill.

Schaal, B. A., K. M. Olsen, and L. J. C. B. Carvalho. 2006. Evolution, Domestication, and Agrobiodiversity in the Tropical Crop Cassava. In Darwin's Harvest: New Approaches to the Origins, Evolution, and Conservation of Crops, edited by T. J. Motley, N. Zerega, and H. Cross, pp. 269-284. Columbia University Press, New York.

Shell, O. A. 2008. Estudios Pano III: Las Lenguas Pano y su Reconstrucción. Instituto Lingüístico de Verano, Lima, Perú.

Smith, Bruce D. 1992. Rivers of Change: Essays on Early Agriculture in Eastern North America. Smithsonian Institution Press, Washington, D.C.

Voort, H. van der. 2007. Proto-Jabutí: Um Primeiro Passo na Reconstrução da Língua Ancestral dos Arikapú e Djeoromitxí. Bol. Mus. Para. Emilio Goeldi. Ciências Humanas 2:133-168.

Walker, R. S., S. Wichmann, T. Mailund, and C. J. Atkisson. 2012. Cultural Phylogenetics of the Tupi Language Family in Lowland South America. PLoS ONE 7(4): e35025. doi:10.1371/ journal.pone.0035025

Wichmann, S. 1995. The Relationship among the MixeZoquean Languages of Mexico. University of Utah Press, Salt Lake City.

Wichmann, S., A. Müller, and V. Velupillai. 2010. Homelands of the World's Language Families: A Quantitative Approach. Diachronica 27:247-276.

\section{Biosketches}

Cecil H. Brown is a linguistic anthropologist with interests in ethnobiology, historical linguistics, and Native American languages.

Charles R. Clement is a geneticist studying the origin and domestication of native Amazonian crops, and the ethnobotany associated with anthropogenic soils and 
other domesticated landscapes.

Patience Epps is a linguist whose work investigates lowland South American languages from historical, typological, and descriptive perspectives.

Eike Luedeling is an agricultural scientist mainly concerned with projection of climate change impacts on agricultural and natural ecosystems and with the development of appropriate adaptation strategies.

Søren Wichmann specializes in quantitative methods in historical linguistics and Mesoamerican languages. He is General Editor of the journal Language Dynamics and Change.

\section{Notes}

${ }^{1}$ This is the second PBL study published in Ethnobiology Letters, the first treating chili pepper (Brown et al. 2013a). Several others are projected. The method and theory of PBL is summarized in Brown et al. (2013a) and discussed in substantial detail in several preceding papers (Brown 2006a,b; Brown 2010; Brown et al. 2013b). The current paper and others that follow in Ethnobiology Letters will not repeat these discussions.

${ }^{2}$ Occasionally, an ASJP date for a proto-language may be older than a date for its own parent language. For example, Proto-Southern Arawakan (4461 BP) has an ASJP date older than that for Proto-Arawakan (4134 BP). This sometimes occurs in ASJP chronology when a language group's breakup is closely followed in time by the breakup of its immediate subgroup. The attested variability of ASJP dates accounts for this apparent aberrancy (Holman et al. 2011:872). 